\title{
PEMBERIAN BANTUAN DAMPAK COVID-19 DOSEN UNIVERSITAS PAMULANG KERJASAMA DENGAN UMKM BABAKAN TANGERANG SELATAN
}

\author{
Irma Sari Octaviani, Lidya Pricilla, Eko Cahyadi, Imbron, Angga Rovita \\ Universitas Pamulang \\ Email: dosen02479@unpam.ac.id
}

\begin{abstract}
In the activities of Community devotion lecturer at Pamulang University, especially our management study Program in cooperation with MSMES South Tangerang provide assistance in the form of food (groceries) for the residents who have the Corona virus. In addition, this activity helps them to do partnership activities through the distribution of basic food to the teachers who do not get the income. The government advises to conduct learning activities through online while their communication tools are still insufficient and the quits are insufficient. In addition, people who are also in the Koran are still in a village that does not have adequate communication tools as well. So it is not possible to study online. We as the management lecturer have a target in this activity to help SMES partnership South Tangerang Increase the activities of SMES in the region, so they can earn income and adequate needs.
\end{abstract}

Keywords: PKM, impact of Covid-19, MSME

\begin{abstract}
Abstrak
Dalam kegiatan Pengabdian Kepada Masyarakat Dosen Universitas Pamulang khususnya Program Studi Manajemen kami melakukan kerjasama dengan UMKM Tangerang Selatan memberikan bantuan berupa pangan (sembako) untuk para warga yang berdmpak virus Corona tersebut.Selain itu, kegiatan ini membantu mereka untuk melakukan kegiatan kemitraan melalui pendistribusian sembako kepada para guru ngaji yang tidak mendapatkan penghasilan tersebut. Pemerintah menyarankan untuk melakukan kegiatan belajar mengajar melalui daring sedangkan mereka alat komunikasinya masih terbilang belum memadai dan kuotanya tidak mencukupi. Selain itu, masyarakat yang mengaji juga masih di dalam perkampungan yang tidak memiliki alat komunikasi yang memadai juga. Sehingga tidak memungkinkan untuk pembelajaran secara daring.Kami selaku Dosen Manajemen memiliki target dalam kegiatan ini untuk membantu kemitraan UMKM Tangerang Selatan meningkatkan kegiatan UMKM di daerahnya, sehingga mereka bisa mendapatkan penghasilan dan mencukupi kebutuhannya.
\end{abstract}

Kata Kunci : PKM, Dampak Covid-19, UMKM 


\section{A. PENDAHULUAN}

Covid-19 merupakan penyakit menular yang disebabkan oleh virus bernama SARSCOV-2, atau seringkali disebut Virus Corona. Virus Corona sendiri merupakan keluarga virus yang sangat besar. Ada yang menginveksi hewan, seperti kucing dan anjing, namun ada pula jenis Virus Corona yang menular ke manusia, seperti yang terjadi pada Covid-19. Covid-19 merupakan penyakit baru, jadi manusia belum punya kekebalan tubuh terhadap Virus SARS-Cov-2. Vaksin dan obatnya belum ditemukan. Saat ini, peneliti di penjuru dunia masih berlomba-lomba mencari vaksin dan obatnya.Kurangnya sosialisasi dan tanggapnya pemerintah terhadap virus ini menyebabkan hampir di seluruh dunia terinfeksi virus Covid-19. Selain itu, masyarakat yang kurang sadar akan pentingnya menjaga kesehatan dan kebersihan Kurangnya sosialisasi Pedoman Pencegahan dan Pengendalian Covid-19 kepada masyarakat, sehingga banyak yang tidak mengetahui bahwa dirinya adalah Orang Dalam Pemantauan (ODP), Pasien dalam Pengawasan (PDP) dan Suspek dan mereka merasa sehat dan masih keluar kota dan keluar negeri, tanpa disadari sudah membawa virus Covid19. Masih banyak juga masyarakat yang tidak mentaati peraturan pemerintah untuk di rumah saja menjadi bagian penyebab kenaikan penularan yang terjadi hampir di 200 negara.Hal tersebut menyebabkan kenaikan kasus yang terinfeksi Covid-19 hampir 200 negara di Dunia. Dari 193 negara yang terinfeksi Covid-19 per tanggal 14 April 2020 sebanyak 1.920.057 orang, sembuh 443.732 orang dan meninggal 119.403. Data yang diperoleh per tanggal 14 April 2020 jumlah yang terinfeksi di Indonesia terus meningkat dengan total 4.839 kasus, dirawat sebanyak 3.954, meninggal 459 dan sembuh sebanyak 426 orang. Dari jumlah tersebut Provinsi DKI Jakarta paling tinggi yang terinfeksi sebanyak 2.335 orang.Hal ini menyebabkan banyak Pemimpin Pemerintah Daerah yang melakukan Lockdown di daerahnya masing-masing untuk mengurangi penularan virus tersebut. Oleh karena itu, Pemerintah Daerah mengajukan Pembatasan Sosial Berskala Besar (PSBB) yang diajukan kepada Menteri Kesehatan yang diatur dalam Undang-Undang No. 6 Tahun 2018 tentang Karantina Kesehatan dan sesuai dengan Keputusan Presiden Republik Indonesia Nomor 11 Tahun 2020 tentang Penetapan Kedaruratan Kesehatan Masyarakat Corona Virus Desease 2019 (Covid-19).Covid-19 penyebarannya luar biasa dengan ditandai jumlah kasus dan/atau jumlah kematian telah meningkat dan meluas lintas wilayah dan lintas negara dan berdampak pada aspek politik, ekonomi, sosial, budaya, pertahanan dan keamanan, serta kesejahteraan masyarakat di Indonesia, maka Presiden mengeluarkan Peraturan Pemerintah Republik Indonesia Nomor 21Tahun 2020, tentang Pembatasan Sosial Berskala Besar Dalam Rangka Percepatan Penanganan Corona Virus Disease 2019 (Covid19).Merujuk dari Undang-Undang dan Peraturan Pemerintah tersebut, beberapa Daerah yang meningkat penyebaran Covid-19 mengajukan PSBB ke kementerian Kesehatan. Isinya diantaranya sebagai berikut:

1. Aktivitas di Luar Rumah

a. Penghentian sementara kegiatan di sekolah dan/atau institusi pendidikan lainnya/belajar di rumah.

b. Penghentian sementara aktivitas bekerja di tempat kerja/kantor dan diganti bekerja dirumah/Work From Home.

c. Tempat ibadah di tutup untuk umum, ibadah di lakukan di rumah masing-masing.

d. Penghentian sementara aktivitas penduduk di tempat/fasilitas umum dengan audiens di atas 5 orang.

e. Penghentian sementara aktivitas sosial dan budaya yang menimbulkan kerumunan orang.

f. Pembatasan penggunaan moda transportasi untuk pergerakan orang dan barang. 
2. Moda Transportasi

a. Untuk pemenuhan kebutuhan pokok

b. Jaga jarak aman antar penumpang

c. Jumlah penumpang dibatasi $50 \%$

3. Pengecualian

Seluruh kantor/instansi pemerintahan, baik pusat maupun daerah berdasarkan pengaturan dari kementrian terkait, BUMN/BUMD yang turut serta dalam penanganan Covid-19 dan/atau dalam pemenuhan kebutuhan pokok masyarakat, pelaku usaha yang bergerak pada sektor:

a. Kesehatan

b. Energi

c. Bahan pangan/makanan/minuman

d. Keuangan

e. Perhotelan

f. Pelayanan dasar, utilitas publik dan industri yang ditetapkan sebagai objek vital nasional dan objek tertentu

g. Organisasi kemasyarakatan lokal dan internasional yang bergerak pada sektor kebencanaan dan.atau sosial kebutuhan sehari-hari

h. industri strategis

i. logistik

j. konstruksi

k. komunikasi dan teknologi informasi

Berkenaan dengan penyebaran Covid-19 yang semakin meningkat di Indonesia, maka kesehatan lahir dan batin siswa, guru, kepala sekolah dan seluruh warga sekolah menjadi pertimbangan utama dalam pelaksanaan kebijakan pendidikan. Oleh karena itu, Kemendikbud mengeluarkan Surat Edaran Nomor 36962/MPK.A/HK/2020, tentang Pembelajaran secara Daring dan Bekerja dari Rumah dalam Rangka Pencegahan Penyebaran Corona Virus Desease (Covid-19), tanggal 17

Maret 2020 dengan ketentuan sebagai berikut:

1. Memberlakukan pembelajaran secara daring dari rumah bagi mahasiswa;

2. Pegawai dan dosen melakukan aktivitas bekerja, mengajar atau memberi kuliah dari rumah (Bekerja dari Rumah/BDR) melalui video conference, digital documents, dan sarana daring lainnya.

3. Pelaksanaan BDR tidak mempengaruhi tingkat kehadiran (dipandang sama seperti bekerja di kantor, sekolah, atau perguruan tinggi), tidak mengurangi kinerja, dan tidak mempengaruhi tunjangan kinerja; dan

4. Apabila harus datang ke kantor/kampus/sekolah sebaiknya tidak menggunakan sarana kendaraan (umum) yang bersifat massal

\section{B. METODE PELAKSANAAN KEGIATAN}

Undang-Undang dan Peraturan Pemerintah. Beberapa masalah utama yang dihadapi oleh UKM antara lain kurangnya permodalan, sumber daya manusia (SDM) yang terbatas, lemahnya jaringan usaha dan kemampuan penetrasi pasar, pemasaran produk, iklim usaha, terbatasnya sarana dan prasarana, sifat produk yang ditawarkan, terbatasnya akses pasar dan lain-lain. Solusinya yaitu dengan beberapa strategi yang bisa dicoba untuk mengubah usaha konvensional yang masih mengandalkan cara lama dalam memulai usaha, untuk bisa beradaptasi dengan perkembangan dunia usaha di situasi industri 4.0 saat ini antara lain : 
1. Memanfaatkan Teknologi

Melakukan kegiatan pemasaran dengan memanfaatkan internet atau dapat membuat pembukuan dengan menggunakan komputer dan masih banyak lagi yang lainnya.

2. Menggunakan digital marketing

Digital marketing adalah aktivitas promosi sebuah brand atau pun produk/jasa menggunakan media elektronik atau digital.adapun teknik pemasaran dalam digital marketing seperti seacrh engine optimization (SEO), billboard elektronik, iklan televisi dan radio, email marketing dan lainnya

3. Mobile friendly

Tingginya jumlah pengguna smarthpone dan produk gadget lainnya juga perlu diperhatikan. Perlu menyesuaikan strategi pemasaran dengan tampilan yang mobile friendly. Sehingga akan lebih banyak orang yang melihat toko online Anda.

4. Menggunakan aplikasi

Dengan menggunakan aplikasi bisa menghemat biaya, waktu dan juga tenaga. Selain itu, aplikasi- aplikasi tersebut juga memberikan kenyamanan dalam penggunaannya.

5. Gunakan sosial media

Indonesia memiliki banyak pengguna sosial media seperti Twitter, Instagram, Facebook, BBM, Line dan sebagainya. Karena itu sosial media dapat dijadikan alat dalam strategi bisnis.

6. Inovasi

Seperti yang diketahui bahwa dunia bisnis sangat cepat berubah, hampir setiap harinya ada saja sebuah trend baru. Oleh karena itu, inovasi sangatlah dibutuhkan agar dapat bersaing dengan kompetitor Anda. Buatlah produk atau jasa Anda berbeda dan istimewa dari yang lain, melalui proses yang baik dan benar

7. Memberikan pelayanan terbaik

Tidak ada yang lebih berharga dalam dunia bisnis dibandingkan dengan memenuhi kebutuhan konsumen. Meskipun, dalam dunia digital Anda juga harus memberikan pelayanan terbaik kepada konsumen Anda.Setelah mendapatkan informasi dari hasil survey yang kami lakukan melalui wawancara melalui daring maka kami langsung membuat kelompok dalam membantu kesulitan para guru ngaji tersebut. Adapun tahapan-tahapan yang kami lakukan dalam Pengabdian Kepada Masyarakat ini diantaranya sebagai berikut:

\section{HASIL DAN PEMBAHASAN}

1. Tahap Persiapan:

a. Survey Awal

Kami melakukan survey kepada UMKM Tangerang Selatan yang menggalang dana untuk para guru ngaji yang membutuhkan. Setelah kami mendapatkan data guru ngaji yang ada diperkampungan yang membutuhkan bantuan dikarenakan tidak mendapatkan penghasilan. Hal ini disebabkan karena tidak boleh melakukan kegiatan di luar rumah dan mereka tidak memiliki alat komunikasi yang memadai untuk melakukan pembelajaran daring.

b. Pemantapan dan penentuan lokasi dan sasaran.

Setelah survey dilakukan maka ditentukan lokasi pelaksanaan dan sasaran yang benarbenar membutuhkan bantuan.Adapun data yang kami dapatkan dari beberapa daerah di babakan tangerang selatan kami telaah dan kami distribusikan ke orang-orang yang benarbenar membutuhkan bantuan. 
2. Tahap Pelaksanaan

Tahap ini kami memberikan donasi kepada UMKM Tangerang Selatan untuk didistribusikan kepada guru ngaji yang tekena Dampak Covid-19 dan bantuan tersebut dibelikan sembako yang mereka butuhkan. Melalui media sosial, dana yang terkumpul kami berikan dan diserahkan melalui transfer ke rekening UMKM Tangerang Selatan dan langsung dibelikan oleh UMKM Tangerang Selatan untuk segera didistribusikan kepada yang membutuhkan.Selain itu, UMKM Tangerang Selatan juga membantu dalam menggiatkan UKM dengan mengajak mereka bergabung dalam UMKM yang ada disekitar mereka. Sehingga ada pemasukan dan pengalaman yang baru dalam mendapatkan penghasilan yang halal dan thoyib.adapun jadwal yang telah disepakati oleh TIM PKM Universitas Pamulang pada tanggal 01 Mei 2020 s/d 03 Mei 2020 Di Babakan Kelapa Dua RT.003 RW.04 Babakan Setu Tangerang Selatan.

Kegiatan dalam memberikan bantuan berupa mendistribusikan sejumlah paket sembako terhadap UMKM yang terdampak Covid-19 yang dilaksanakan pada tanggal 01 Mei $2020 \mathrm{~s} / \mathrm{d}$ 03 Mei 2020 Di Babakan Kelapa Dua RT.003 RW.04 Babakan Setu Tangerang Selatan berjalan dengan baik yang bertujuan agar dapat membantu meringankan beban UMKM yang terkena dampak akibat adanya covid-19 dengan menggunakan metode diskusi dan seminar agar mendapatkan penghasilan yang cukup untuk memenuhi kebutuhannya terlebih dimasa pandemi saat ini dengan memberikan penyuluhan pemanfaatan teknologi yang dapat membantu melakukan pemasaran terhadap produk yang akan diperdagangkan. Meskipun disaat pandemi ruang gerak terbatas namun tetap masih bisa berpenghasilan dengan menggunakan teknologi era digital

\section{KESIMPULAN DAN SARAN}

\section{Kesimpulan}

Dengan adanya Pandemi Covid-19 mereka tidak mendapatkan penghasilan dikarenakan semuanya tidak diizinkan untuk keluar rumah. Oleh karena itu Dosen Universitas Pamulang khususnya Program Studi Manajemen bekerjasama dengan UMKM Tangerang Selatan memberikan bantuan berupa pangan (sembako) untuk para warga UMKM Tangerang Selatan. Selain itu, kegiatan ini membantu mereka untuk melakukan kegiatan kemitraan melalui pendistribusian sembako kepada para guru ngaji yang tidak mendapatkan penghasilan tersebut. Pemerintah menyarankan untuk melakukan kegiatan belajar mengajar melalui daring sedangkan mereka alat komunikasinya masih terbilang belum memadai dan kuotanya tidak mencukupi. Selain itu, masyarakat yang mengaji juga masih di dalam perkampungan yang tidak memiliki alat komunikasi yang memadai juga. Sehingga tidak memungkinkan untuk pembelajaran secara daring. Kami selaku Dosen Manajemen memberikan masukan kepada mereka untuk membantu kemitraan UMKM Tangerang Selatan meningkatkan kegiatan UMKM di daerahnya, sehingga mereka bisa mendapatkan penghasilan dan mencukupi kebutuhannya.

\section{Saran}

1. Memanfaatkan teknologi yang ada saat ini untuk membantu dan memudahkan dalam pekerjaan (Bisnis) dengan digital marketing untuk memasarkan produk UMKM karena selama pandemi semua hanya bisa dilakukan dengan dirumah saja dengan mengikuti protokol kesehatan dari pemerintah. 
2. Para Pelaku UMKM harus selalu berinovasi dalam menciptakan produk yang berkualitas untuk masyarakat luas dan selalu mengevaluasi agar bisa maksimal dalam menghasilkan produk.

\section{DAFTAR PUSTAKA}

Pasal 4 ayat (1) Undang-Undang Dasar Negara Republik Indonesia Tahun 1945;

UU No. 6 Tahun 2018 tentang Karantina Kesehatan (Lembaran Negara Republik Indonesia Tahun 2018 Nomor 128, Tambahan Lembaran Negara Republik Indonesia Nomor 6236);

Peraturan Pemerintah Republik Indonesia Nomor 21 tahun 2020 Tentang Pembatasan Sosial Berskala Besar Dalam Rangka Percepatan Penanganan Corona Virus Disease 2019 (Covid-19);

Keputusan Presiden Republik IndonesiaNomor 11 tahun 2020 Tentang Penetapan Kedaruratan Kesehatan Masyarakat Corona Virus Disease 2019 (Covid- 19);

Peraturan Menteri Pendidikan Dan Kebudayaan Republik Indonesia Nomor 3 tahun 2020 Tentang Standar Nasional Pendidikan Tinggi;

Peraturan Menteri Pendidikan Dan Kebudayaan Republik Indonesia Nomor 7 Tahun 2020 Tentang Pendirian, Perubahan, Pembubaran Perguruan Tinggi Negeri, Dan Pendirian, Perubahan, Pencabutan Izin Perguruan Tinggi Swasta;

Surat Keputusan Menteri Kesehatan Nomor HK.01.07 /Menkes/239/2020, tentang Penetapan Pembatasan Sosial Berskala Besar di Wilayah Provinsi DKI Jakarta Dalam Rangka Percepatan Penanganan Corona Virus Disease 2019 (COVID 19);

Surat Edaran Nomor 2 Tahun 2020 tentang Pencegahan dan Penanganan COVID-19 di Lingkungan Kemendikbud; 